\title{
List of Figures and Tables
}

\section{Figures}

4.1. Short-Term Effectiveness by Covert Tactic 77

4.2. Short-Term Effectiveness by Cold War Alliance 81

4.3. US-Backed Covert Regime Change and MIDs: Bivariate Correlations $\quad 86$

4.4. US-Backed Covert Regime Change and Average Change in Polity Score

4.5. US-Backed Covert Regime Change and Civil War: Bivariate Correlations

4.6. US-Backed Covert Regime Change and Mass Killings: Bivariate Correlations

5.1. US-Backed Regime Change Attempts by Administration, 1947-1989

\section{Tables}

1.1. US-Backed Regime Change Attempts during the Cold War (1947-1989)

2.1. Case Selection and Alternative Hypotheses on the Causes of Regime Change

2.2. Regime Type of Target States-Difference of Proportions Test 
4.1. Probit Analysis of Short-Term Effectiveness

4.2. US-Backed Covert Regime Change and MIDs: Probit Analysis

4.3. US-Backed Covert Regime Change and Civil War: Probit Analysis

4.4. US-Backed Covert Regime Change and Mass Killing: Probit Analysis

5.1. US-Backed Offensive Covert Regime Change Attempts during the Cold War

5.2. US-Backed Preventive Covert Regime Change Attempts during the Cold War

5.3. US-Backed Hegemonic Covert Regime Change Attempts during the Cold War 